\title{
ICT and OER-Integrated Teaching and Learning: Supporting Social Change among Teachers in a Post-War Northern Sri Lanka
}

\author{
Sasikala Kugamoorthy* and M. Rajini \\ Department of Secondary \& Tertiary Education, Faculty of Education, The \\ Open University of Sri Lanka
}

\begin{abstract}
This paper examines the contribution of Information and Communication Technology (ICT) and Open Educational Resources (OER) integrated teaching and learning for supporting social change among teachers in the post war Northern Sri Lanka. It is a case study exploring the experiences and reflections of a cohort of teachers from Northern Sri Lanka who were very recently exposed to use, create and share OER in their teaching-learning process, using ICT. Data was collected from 38 student teachers of Post Graduate Diploma in Education Programme at the Jaffna Regional Centre (JRC) of the Open University of Sri Lanka (OUSL) using questionnaire surveys, interviews, concept mapping, classroom observations and self-reflections. Findings revealed that ICT and OER -integrated teaching and learning has been instrumental in changing teachers' thinking patterns and their social behaviours in a positive manner as well as building social relationships. These indicate the important role of ICT and OER-integrated teaching and learning in bringing about social change in a post-conflict social setting.
\end{abstract}

Keywords: ICT and OER-integrated teaching and learning, Teacher Professional Development, Social Change, Northern Sri Lanka.

\section{Introduction}

The end of three decades ethnic war in Sri Lanka has brought widespread expectations of development, economic stability and prosperity. The post war context enabled the country to embark on a development era. The

\footnotetext{
* Corresponding Author: Sasikala Kugamoorthy email: skuga@ou.ac.lk

(i) http://orcid.org/0000-0002-7330-9733

(Received 26 February 2017; Revised 26 April 2017; Accepted 19 May 2017)

(C) OUSL
} 
Northern part of the country was the worst affected region and there is a need for socio-economic development to make this region on par with the other regions of the country. Under the post-war context, the Northern part of the country is slowly but steadily moving forward with a hope to regain its past glory. As education plays the key role in the promotion of social changes and development of any country which is affected by conflicts and disasters, people in the Northern region have great expectations for their education and are keen on safeguarding their right for education and development.

As cited in Lingenfelter (2012), Peter Drucker (1969) states that in the era of knowledge economy, knowledge will be the key source of a knowledge society in which knowledge workers will be the dominant group in the workforce. Therefore, knowledge generation and transmission have become the integral processes of development in the contemporary world. Children in post-war Sri Lanka need to develop appropriate knowledge, skills, attitudes and perspectives to regain their prosperity and to live in this age of information technology. Provision of technologically-enhanced education will support the children to face the demands of this era. Technology can be used as a powerful tool to make classroom instruction easier, more interesting and motivating. Further, modern Information Communication Technology (ICT) integration in education will bring about greater economic, social and educational improvements.

In addition, the use of Open Educational Resources (OER), which are freely and openly available quality educational resources will enable teachers to adopt innovative approaches in their teaching and learning process and to make education accessible to all children. As teachers are the key sources of knowledge and education and play a key role in shaping the next generation of Sri Lanka, they should develop the skills and confidence to integrate ICT and OER in their professional practices.

As part of the Research on Open Educational Resources for Development (ROER4D) programme, a project was undertaken by the Faculty of Education of the Open University of Sri Lanka (OUSL) to engage student teachers of its' Post Graduate Diploma in Education (PGDE) programme to integrate OER in their teaching-learning process and studying it's impact. This project was implemented in nine centres of OUSL representing nine provinces including Jaffna in the Northern Province of Sri Lanka. This study is an attempt to explore the experiences of teachers from Northern Sri Lanka in the process 
of integration of OER in their teaching and learning activities. This study also tries to delineate reflections of teachers from a conflict affected region who were very recently exposed to OER and experienced the effect of ICT and OER integration in their teaching-learning process.

\section{Theoretical Framework and Review of Literature}

\section{Social change through technology integration}

Society is a complex network of patterns of relationships in which all the members participate in varying degrees and contribute to changes in relationships and behaviours. Social change means modifications of the way people work, rear a family, educate their children, govern them and seek ultimate meaning in life. But the conceptualization of social change can be approached from a number of directions. William Ogburn's theory of social change asserts that technology is the basic cause of social change. As cited in Mutekwe (2012), Ogburn (1964) identified technology as the primary engine of progress and it drives the development of social structure and cultural values. He further argues that, social change comes through a three- pronged process - invention, discovery and diffusion. Invention is a combination of existing elements and materials to form new ones (Vago 1992; Henslin, 1998); Discovery, is a new way of seeing reality (Vago, 1992); Diffusion, is the spread of invention or discovery from one area to another (Henslin, 1998). Diffusion is viewed as the major process of social change that can have far reaching effects on human relationships.

Social change is not only a change in the structure, but also in the functioning of society, comprising modifications in social systems or subsystems in structure, functioning, or process over some period of time (Allen, 1971). Tonnies (1988), as cited in Mutekwe (2012), discussing about socio-cultural changes from traditional to modern types of society, claims that technology is the organizing force for social life, and when it changes, its' effects can be profound.

Among various theories on social change, Technological Theory is the theoretical base for this present study because technology will enhance the access of OER and support the integration of OER in teaching and learning practices. According to Schaefer and Lamm, (1992) as cited in Mutekwe (2012) the term 'technology' refers to the creation of tools and materials 
using knowledge and their utilization for human interaction with nature. Technological theory suggests that, technology is an important factor for social change and it would initiate changes in the arrangement of social relationships. In addition, the analysis of reflections of participants in a project on integration of OER and ICT to Open Distance Learning (ODL) programmes, revealed that, features like hands on experiences, excellent facilitation, guidance and support, motivation and satisfaction gained through the activities facilitated participants' thinking process and created a mutual understanding and close relationship among the members (Karunanayaka \& Naidu, 2014).

The literature revealed that the technology fosters social change by changing social behavior and thinking patterns of individuals in the society and by improving their social relationships.

\section{Facing educational challenges in post-conflict contexts}

Teachers and students in the post war contexts or so called conflict affected fragile environments experience extra ordinary challenges even for the basic education delivery. These challenges keep them away from the use of technology-enhanced education. These aspects negatively affect students' cognitive, physical and psycho-social well-being, which in turn negatively affect their learning.

Teachers are directly affected by conflicts and crisis. Their own education and professional development may have been disrupted and resulting in low levels of content knowledge and teaching skills (USAID, 2013). Kelegama (2010), in a report on post conflict reconstruction in Sri Lanka, mentions that, education of most of the students in conflict affected areas was disrupted due to displacement, loss of family members, psychological impact, loss of school materials and the destruction of school buildings. Further, he suggests that providing educational infrastructure including teaching and learning aids is an essential action that should be considered regarding the conflict affected groups. His ideas reveal that provision of teaching learning materials is also an important action to promote educational gains of post conflict regions.

In Northern Sri Lanka, due to the armed conflict, the educational gains were impaired or reversed over many years. The educational infrastructure has 
been severely damaged and has made serious impact on the provision and service delivery of education. In a study conducted in three districts in Northern Sri Lanka, Kugamoorthy, Thanaraj, Lekamge and Zarookdeen (2013) observed that during the prolonged conflict, the school buildings and infrastructure were damaged or destroyed. This indicates that traditional classroom setting has been severely affected by the armed conflict. Thus, other means of teaching and learning have to be sought and introduced. As e-learning can provide learning opportunities anytime and anywhere and enable the students and instructors to use a wide range of Internet based tools to communicate, collaborate and share resources, and open up accessible educational opportunities, it appears to be a promising alternative for such conflict contexts. ICT and e-learning could be used as reconstructive and attractive measures to support the affected learners and teachers (Rhema \& Miliszewska, 2012).

As Northern Sri Lanka has been severely affected by the conflict for the last three decades, it is also difficult to provide appropriate teaching and learning materials and quality education in that region. Conflict and crisis affected environments are particularly challenging, but ICT has considerable potential to improve the quality of education in that setting (USAID, 2013). In addition, Kelegama (2010) also mentions that these conflict affected regions have many issues including the lack of teaching and learning materials and technology which can be used to integrate teaching-learning resources in an effective manner to provide quality education.

Kelly (2013) claims that access to technology brings young people into contact with the broader world, opening up access to education and vocational training in a very cost effective way and has transcended poverty, race and economics to become a driving force in the lives of people across the world. Hennessy et al. (2010) also claim that ICT is a principal driver of economic development and social change worldwide. They further indicate that ICT plays a major role in all aspects of life: in politics, in economic life, as well as in social and cultural development. Therefore, it is obvious that the integration of ICT in education will bring about many social changes and will enable social mobility of people.

As quality educational resources with no cost, integration of OER in teaching and learning will enable the region affected by internal conflict to rebuild its glory through technologically-enhanced education. ICT and e-learning can be 
used as a vehicle for the access of OER of all forms and to provide high quality education for the children in the disadvantaged environments.

\section{OER-integrated teaching and learning to support social change}

The term Open Educational Resources was first introduced at a conference hosted by UNESCO in 2000 and was promoted in the context of providing free access to educational resources on a global scale. Open Educational Resources (OER) are 'teaching, learning and research materials in any medium digital or otherwise, that reside in the public domain or have been released under an open license that permits no cost access, use, adaptation and redistribution by others with no or limited restrictions' (UNESCO, 2012). OER may include full courses, course materials, modules, textbooks, streaming videos, tests, software, and any other tools, materials, or techniques used to support access to knowledge. OER can be used freely and openly in the teaching-learning process and the enhanced openness through OER empowers teachers and learners to become more creative and innovative in their educational practices (Cape Town Open Education Declaration, 2008).

OER have many positive impacts in the teaching and learning process. Using the tools offered by new ICT, integration of OER will not only increase capacity for teaching training system but also offer opportunities to enhance articulation between theory and practice and to support teachers more effectively to become reflective practitioners (Thakrar, Zinn \& Wolfendon, 2009). In an analysis of reflections of teachers participated in a case study in Jaffna, the results indicated that integration of OER in their teaching and learning process has provided opportunities to overcome their obstacles, to become enthusiastic participants and involve actively in teaching and learning processes (Kugamoorthy \& Rajini, 2016).

In addition, OER have many benefits including free and open availability and accessibility over the Internet and as few restrictions as possible on the use of the resources. There should be no technical barriers, no price barriers and as few legal permission barriers as possible for the end-user. Unlike other traditional educational materials which are protected under conventional copyright terms, OER have an open license which allows the end user to use, modify and share them at no cost. Open licenses permit the users to retain, reuse, remix, revise and redistribute the OER materials (Wiley, 2014). 
Therefore, teachers can use OER in a productive way to create their own materials and use them to provide innovative teaching and learning experiences. These innovative experiences may bring about changes in the behaviour of students and to promote their social relationships.

Rapid advancements in ICT enables teachers to easily create and share digital content and resources in the form of OER. The real educational potential of OER has two dimensions- the pedagogical and the digital (UNESCO/COL, 2011). With the new trends in ICT, access to resources and flexibility in teaching-learning process have expanded, enhancing resource-based teaching and learning. Also, by allowing free and open sharing of resources and teaching-learning practices through technology, OER can facilitate a collaborative approach to generation of knowledge (Geser, 2007). Similarly, Atkins, Brown and Hammond (2007) also state that OER have the potential to play a pivotal role in democratizing access to knowledge in ways that have a special relevance to education system in developing countries. Further, UNESCO (2010) reports that the advantage of OER in crisis and conflict situations is that learning materials can be made available rapidly, at low cost, and adapted locally to suit specific target group needs, using ICT.

Atkins et. al. (2007) further pointed out that, OER have the potential to obviate demographic, economic and geographic educational boundaries and promote life-long learning and personalized learning. Similarly, Yuan, MacNeil and Kraan (2008), also stated that learning is a social process based on ongoing communication, exchange of ideas and opinions and the reconsideration and reworking of study results. From a social and pedagogical perspective, OER could support lifelong learning and personalized learning and will move the power over learning from the institutions to individual learners. Quality of learning experiences can be improved through facilitating learner centered, self-directed, peer to peer and social learning by the integration of ICT and OER.

As literature reveals, integration of ICT and OER in teaching and learning in conflict affected contexts and developing countries have great importance. Mainly because, they save costs for students in such disadvantaged areas who cannot afford to buy expensive text books and other course materials. Further, OER have a high social responsibility in such contexts and provide education for all and raise the standard of educational resources. 
Integration of ICT and OER in educational practices enable to overcome the obstacles of time and space. It could be used to gain an understanding of others, meet people all over the world, maintain and strengthen familial relationships, communicate effectively with others and help people to become more socially adept. Ghavifekr and Rosdy (2005) conducted a study to analyse teachers' perceptions on the effectiveness of ICT integration to support teaching and learning process in classroom, and found that ICT helps students to learn more effectively, broaden students' knowledge, encourages them to communicate more with their classmates and increased their self-confidence. In another case study conducted in Singapore, Finland and Egypt by Kosma (2005), ICT was identified as the principal driver of economic development and social change. The findings further indicated that, ICT based education may make a significant contribution to the launch of social and economic development. Therefore, integration of ICT and OER will not only facilitate the teaching-learning process but also build a learning community with enormous social skills in the conflict affected countries.

Education is a critical element in rebuilding shattered societies and restoring stability to areas affected by conflict. It can heal the psychological wounds of war, curb youth unemployment, build peace and promote economic and social development. Much research in the area of technology integration in education has been conducted in technologically-advanced countries, but little in the so-called developing or third world countries. The present study attempts to investigate the social changes caused by the integration of ICT and OER in the teaching-learning process in the post war context in Northern Sri Lanka that has been severely affected by the conflict for the last three decades and is now progressing towards development using education as one main tool.

\section{Purpose of the study}

This paper deals with the experiences of graduate teachers from war affected regions of Northern Sri Lanka who were exposed to use OER in their teachinglearning process, through a professional development intervention programme. The paper aims to ascertain the effects of ICT and OER integrated teaching and learning as an agent of social change in a post war context in Northern Sri Lanka. For this purpose, the following research questions were formulated. 
1. What is the effect of integration of ICT and OER in teaching and learning on teachers' thinking patterns in relation to social change?

2. To what extent has integration of ICT and OER affected the changing of teachers' social behaviours?

3. How has the integration of ICT and OER affected the teachers' social relations?

\section{Methodology}

\section{Research Design}

A case study research design using a qualitative research approach was adopted in this exploration of the effects of ICT and OER integration on social change among teachers.

\section{Participants}

The participants of the study consisted of a group of 38 student teachers following PGDE Programme 2014/2015 at the Jaffna Regional Centre of the OUSL. Table 1 describes the background information of the participants.

Among the 38 student teachers, 24 were male and 14 were female. All of them had less than 10 years of teaching experience. 13 teachers taught Science, 13 Mathematics, 8 ICT, 2 civics, 1 Health science and I taught music. Further, 12 of them taught at urban schools whereas others taught at rural and semi urban schools. 3 of them were from private schools. The participants represented participants from different socio-economic contexts. 
Table I: Description of sample

\begin{tabular}{|c|c|c|c|}
\hline Personal Details & Characteristics & Number & Percentage \\
\hline \multirow[t]{2}{*}{ Gender } & Male & 24 & 63 \\
\hline & Female & 14 & 37 \\
\hline \multirow[t]{11}{*}{ Subject taught } & Science & 11 & 29 \\
\hline & Mathematics & 15 & 39 \\
\hline & Commerce & 2 & 5 \\
\hline & IT & 8 & 21 \\
\hline & Biology & 3 & 8 \\
\hline & Physics & 3 & 8 \\
\hline & Chemistry & 4 & 11 \\
\hline & Language & 3 & 8 \\
\hline & Religion & 2 & 5 \\
\hline & Aesthetics & 2 & 5 \\
\hline & Other & 8 & 21 \\
\hline \multirow[t]{5}{*}{ First Degree } & B.Sc & 23 & 61 \\
\hline & B.A & 12 & 32 \\
\hline & B.Com & 0 & 0 \\
\hline & BFA & 1 & 3 \\
\hline & Other & 2 & 5 \\
\hline $\begin{array}{l}\text { Post graduate } \\
\text { qualifications }\end{array}$ & Masters' Degree & 6 & 16 \\
\hline \multirow[t]{5}{*}{ Teaching Experience } & $\leq 5$ & 30 & 79 \\
\hline & yr.6-10 & 7 & 18 \\
\hline & Yr.11-15 & 0 & 0 \\
\hline & yr.16-20 & 0 & 0 \\
\hline & $>20$ & 0 & 0 \\
\hline
\end{tabular}

\section{Data Collection}

In this exploratory case study, a combination of methods including questionnaire surveys, concept mapping, interviews, classroom observations and self-reflections were used for data collection.

Data collection commenced in March 2015 and was completed in January 2016. Three questionnaire surveys were administered: A pre-intervention survey in March 2015, mid- intervention survey in July 2015 and Postintervention survey in January 2016. 
The participants were instructed to upload their concept maps in the Learning Management System (LMS) after their participation in intervention workshops conducted by the research team. In addition, hard copies of the concept maps were also collected. Focus group interviews were conducted immediately after each workshop with an aim to get in-depth information. Participants for the focus group interview were selected based on the subjects they taught.

Self- reflections uploaded by the participant teachers in the discussion forum were also used to collect data on their thinking patterns.

One research team member observed OER integrated lessons in schools over a period of 2-4 weeks. Each observed lesson was video recorded. A total of fifteen lessons were observed in three different subject areas including Mathematics, Science and ICT.

\section{Data Analysis}

Student teachers' responses to the questionnaire survey were analysed using frequencies and percentages. The classroom observation data was analysed according to the observation criteria. The data obtained from concept maps, interviews and reflections were analysed qualitatively and grouped under themes and categories.

\section{Results and Discussion}

This section presents the findings of the study with respect to participant teachers' responses to the questionnaire survey and interviews; their reflections and expressions in the concept maps; and the data collected from classroom observations.

\section{What is the effect of integration of ICT and OER in teaching and learning on teachers' thinking patterns in relation to social change?}

The effects of ICT and OER integrated teaching and learning on teachers' thinking patterns were explored by the analysis of their responses to the interviews, their reflections and concept maps. Table 2 summarizes the participant teachers' thoughts expressed in their concept maps in relation to the changes in their thinking patterns. 
Table 2: Changes in teachers' thoughts and concepts

\begin{tabular}{|c|c|c|c|c|c|c|}
\hline \multirow[t]{2}{*}{$\begin{array}{l}\text { Categori } \\
\text { es }\end{array}$} & \multirow[t]{2}{*}{$\begin{array}{l}\text { Key/Focal } \\
\text { concepts }\end{array}$} & \multirow[t]{2}{*}{ Related concepts } & \multicolumn{2}{|c|}{$\begin{array}{l}\text { After the pre- } \\
\text { intervention } \\
\text { workshop }\end{array}$} & \multicolumn{2}{|c|}{$\begin{array}{l}\text { After the post } \\
\text { intervention/E } \\
\text { valuation } \\
\text { workshop }\end{array}$} \\
\hline & & & $\mathrm{N}$ & $\%$ & $\mathrm{~N}$ & $\%$ \\
\hline \multirow{3}{*}{$\begin{array}{l}\text { Professi } \\
\text { onal } \\
\text { aspects }\end{array}$} & \multirow[t]{3}{*}{ Teaching } & Effective teaching & 4 & 10.5 & 20 & 52.6 \\
\hline & & $\begin{array}{l}\text { Innovative teaching } \\
\text { methods }\end{array}$ & 5 & 13.5 & 12 & 31.6 \\
\hline & & Skill development & 5 & 13.5 & 15 & 40.5 \\
\hline \multirow[t]{9}{*}{$\begin{array}{l}\text { Social } \\
\text { aspects }\end{array}$} & \multirow[t]{3}{*}{ Sharing } & $\begin{array}{l}\text { Exchange of } \\
\text { information }\end{array}$ & - & & 22 & 57.8 \\
\hline & & Sharing lesson plans & 4 & 10.5 & 21 & 55.2 \\
\hline & & $\begin{array}{l}\text { Sharing teaching and } \\
\text { learning materials }\end{array}$ & 15 & 40.5 & 21 & 55.2 \\
\hline & \multirow[t]{3}{*}{ Social skills } & Leadership & 3 & 7.8 & 13 & 34.2 \\
\hline & & Cooperation & 5 & 13.5 & 16 & 43.1 \\
\hline & & Creativity & 4 & 10.5 & 12 & 31.6 \\
\hline & \multirow{3}{*}{$\begin{array}{l}\text { Relationshi } \\
\text { ps }\end{array}$} & Link with academics & - & & 15 & 40.5 \\
\hline & & Peer interactions & 5 & 13.5 & 18 & 47.3 \\
\hline & & $\begin{array}{l}\text { Relationship with } \\
\text { students }\end{array}$ & 8 & 20.1 & 21 & 55.2 \\
\hline
\end{tabular}

Table 2 illustrates the changes in participant teachers' concepts and thoughts. Initially the participants' thoughts on professional as well as social aspects were very limited. However, after the integration of ICT and OER in their teaching and learning process, their concepts and thoughts became broader. More than $50 \%$ of the teachers expressed that their teaching became effective, they exchanged information with their colleagues through workshops and seminars and shared lesson plans and teaching and learning materials. Further they indicated that, their relationship with students became closer. In addition, $40.5 \%$ of the teachers expressed that their links with academics also improved. Therefore, the analysis of the data from the concepts maps revealed that, teachers' concepts and thoughts have significantly changed through the integration of ICT and OER in their teaching and learning process. 
Table 3 summarizes the data collected from the reflective notes in relation to the changes in their thinking patterns.

Table 3: Changes in teachers' thinking patterns in relation to social change

\begin{tabular}{|c|c|c|c|}
\hline \multirow[t]{2}{*}{ Categories } & \multirow[t]{2}{*}{ Codes } & \multicolumn{2}{|c|}{ Supportive Quotes } \\
\hline & & Pre-Intervention & Post Intervention \\
\hline \multirow[t]{2}{*}{ Beliefs } & OER & $\begin{array}{l}\text {....no idea about } \\
\text { OER... }\end{array}$ & $\begin{array}{l}\text {....got more clear idea } \\
\text { about integrating OER... }\end{array}$ \\
\hline & Copyrights & $\begin{array}{l}\text {...used internet } \\
\text { resources without } \\
\text { any consideration } \\
\text { about copyrights... }\end{array}$ & $\begin{array}{l}\text {...got to know about the CC } \\
\text { licenses... gave us a nice } \\
\text { opportunity to manipulate } \\
\text { the resources legally.... }\end{array}$ \\
\hline \multirow[t]{5}{*}{ Attitudes } & Technology & $\begin{array}{l}\text {....didn't have enough } \\
\text { knowledge of using } \\
\text { computers... }\end{array}$ & $\begin{array}{l}\text {...got a good image in the } \\
\text { society by the use of new } \\
\text { technology and felt proud... }\end{array}$ \\
\hline & Language & $\begin{array}{l}\text {... affected by lack of } \\
\text { English knowledge... }\end{array}$ & $\begin{array}{l}\text {....now able to integrate } \\
\text { several OER which are in } \\
\text { English.... feel confident... }\end{array}$ \\
\hline & Resources & $\begin{array}{l}\text {...lack of computer } \\
\text { labs, internet } \\
\text { connection and } \\
\text { electricity... }\end{array}$ & $\begin{array}{l}\text {...tried to get all the } \\
\text { facilities need to integrate } \\
\text { OER in our lessons... }\end{array}$ \\
\hline & Innovation & $\begin{array}{l}\text {...Because of the } \\
\text { language problem we } \\
\text { felt its' difficult to use } \\
\text { web based resources } \\
\text { in teaching... }\end{array}$ & $\begin{array}{l}\text {... I realized the importance } \\
\text { of mother tongue and } \\
\text { designed an OER page on } \\
\text { 'tamil.wikipedia'... }\end{array}$ \\
\hline & Creativity & $\begin{array}{l}\text {... difficult to find the } \\
\text { proper subject } \\
\text { materials... spent } \\
\text { more time... }\end{array}$ & $\begin{array}{l}\text {..realized the benefits of } \\
\text { OER .... published a } \\
\text { handbook of OER which is a } \\
\text { good resource for relevant } \\
\text { OER links... }\end{array}$ \\
\hline
\end{tabular}

The analysis of data revealed that participant teachers in Jaffna initially had limited knowledge on OER. Yet the intervention on integration of OER in the teaching-learning process significantly changed their thinking patterns and raised their awareness on OER and sharing the resources with others.

During the interviews, participant teachers expressed the changes in their thinking patterns as follows: 
"Our ideas related to online resources are changed entirely after attending the workshop on Integrating OER in Teaching and Learning"

"We were able to improve our way of thinking and to get familiar with modern technology. It helped us to improve the quality of our teaching"

"We found teaching became interesting and productive and we felt happy and satisfied as the students seemed to be motivated"

"We also published a handbook with OER links for selected subjects. We felt happy and satisfied through these practices"

Another teacher showed her satisfaction of OER integration by the following statement:

"We felt that we have refreshed our teaching learning process through the integration of OERs"

The data revealed that adoption of OER in teaching and learning practices has positively affected their thinking patterns. Their motivation and satisfaction of ICT and OER integration was quite significant. A majority of the teachers willingly shared their OER-integrated lessons with their peer teachers. Further, they designed and created new OERs in their mother tongue- Tamil. They also published a handbook of a collection of OER they found and used. The integration of ICT and OER in teaching and learning process has positively changed teachers' thinking patterns relating to social change.

\section{To what extent has integration of ICT and OER affected the changing of} teachers' social behaviours?

Data collected from classroom observations, interviews and questionnaire surveys were used to examine the extent to which the integration of ICT and OER has affected teachers' social behaviours. Table 4 summarizes the changes in teachers' social behaviours. 
Table 4: Changes in teachers' social behaviours

\begin{tabular}{|c|c|c|c|}
\hline \multirow[t]{2}{*}{ Categories } & \multirow[t]{2}{*}{ Codes } & \multicolumn{2}{|c|}{ Supportive Quotes } \\
\hline & & Pre-Intervention & Post Intervention \\
\hline \multirow[t]{3}{*}{$\begin{array}{l}\text { Social } \\
\text { skills }\end{array}$} & Personality & $\begin{array}{l}\text {...some barriers } \\
\text { demotivated us at } \\
\text { many instances.... }\end{array}$ & $\begin{array}{l}\text {...OER enhanced our } \\
\text { thinking capabilities } \\
\text { and...development of our } \\
\text { personalities as well... }\end{array}$ \\
\hline & Leadership & $\begin{array}{l}\text {....no opportunities to } \\
\text { take leadership } \\
\text { roles...felt } \\
\text { demotivated.... }\end{array}$ & $\begin{array}{l}\text {... lead and organized the } \\
\text { OER workshop and } \\
\text { conducted it in a successful } \\
\text { manner... }\end{array}$ \\
\hline & Team spirit & $\begin{array}{l}\text {...teach in remote } \\
\text { areas... work alone...no } \\
\text { opportunities to work } \\
\text { as a team... }\end{array}$ & $\begin{array}{l}\text {...successfully conducted an } \\
\text { awareness raising } \\
\text { programme as a team... }\end{array}$ \\
\hline \multirow[t]{2}{*}{$\begin{array}{l}\text { Social } \\
\text { attitudes }\end{array}$} & $\begin{array}{l}\text { Facing } \\
\text { challenges }\end{array}$ & $\begin{array}{l}\text {...faced many } \\
\text { challenges... computer } \\
\text { and internet } \\
\text { facilities...technical } \\
\text { issues... }\end{array}$ & $\begin{array}{l}\text {.....great interest in OERs } \\
\text { motivated us to overcome } \\
\text { these barriers with great } \\
\text { enthusiasm... }\end{array}$ \\
\hline & Sharing & $\begin{array}{l}\text {...due to language } \\
\text { issues...shy to share... }\end{array}$ & $\begin{array}{l}\text {...found and shared OER in } \\
\text { English and Tamil.....shared } \\
\text { ideas... }\end{array}$ \\
\hline
\end{tabular}

Teachers expressed their feelings on the changes they experienced through ICT and OER integration as follows:

"We were able to change the way of teaching from traditional method into student-centred approach. We also shared the facts we got to know about OER with our colleagues and encouraged them to apply. We also felt some sort of changes in our personality through OER"

Participant teachers conducted OER-integrated lessons through which they were able to develop many social behaviours among themselves as well as among students. Table 5 summarizes the observations of their OERintegrated lessons. 
Table 5: Classroom observations of OER-integrated lessons

\begin{tabular}{|c|c|c|c|}
\hline $\begin{array}{l}\text { Grade/ } \\
\text { Subject }\end{array}$ & Lesson topic & How OER were integrated & $\begin{array}{c}\text { Social } \\
\text { behaviours }\end{array}$ \\
\hline Gr10 Science & Cell Structure & Diagrams to introduce basic cell-structure and to illustrate organelles. & \multirow{15}{*}{ 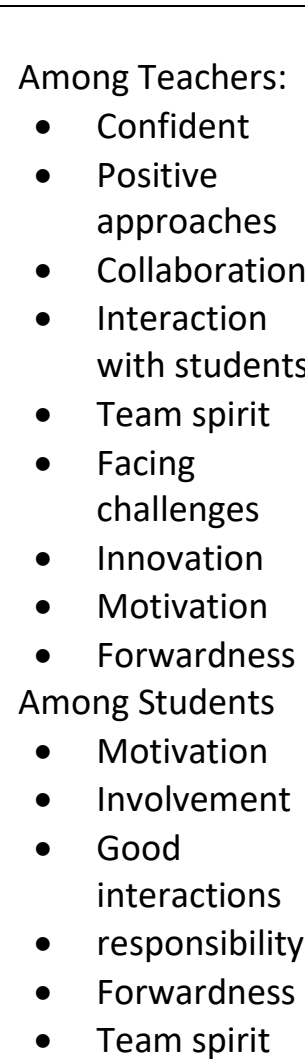 } \\
\hline Gr6 Science & Electricity & Diagrams of electronic devices such as LED, Diode for activities & \\
\hline r9 Science & $\begin{array}{l}\text { Refraction of } \\
\text { Light }\end{array}$ & $\begin{array}{l}\text { Photos to show the effects of refraction of light, with demonstration } \\
\text { Diagrams to illustrate examples for refraction of light. }\end{array}$ & \\
\hline Gr10 Science & $\begin{array}{l}\text { Changes of } \\
\text { matter }\end{array}$ & Photos to elaborate some observations of physical/ chemical changes & \\
\hline Gr8 Science & Light & $\begin{array}{l}\text { Photos to illustrate examples for luminous and non-luminous } \\
\text { materials. }\end{array}$ & \\
\hline Gr9 Science & Animal diversity & Photos to show some extinct species. & \\
\hline Gr8 Science & Plant diversity & Photos to show some modifications of stem & \\
\hline Gr7 Science & simple machines & Photos, diagrams and animations to show some simple machines. & \\
\hline Gr9 Science & Light & Photos and diagrams to show some characteristics of light rays. & \\
\hline $\begin{array}{l}\text { Gr7 } \\
\text { Mathematics }\end{array}$ & Lines & Photos and diagrams to illustrate the types of lines. & \\
\hline $\begin{array}{l}\text { Gr9 } \\
\text { Mathematics }\end{array}$ & Probability & Small video clips to illustrate the probability. & \\
\hline Gr10 ICT & Functions & OER document to explain SUM functions. & \\
\hline $\begin{array}{l}\text { Gr7 } \\
\text { Mathematics }\end{array}$ & Solids & $\begin{array}{l}\text { Photos and diagrams to illustrate some examples for different shapes } \\
\text { of solids and activities in number of edges and faces in some solids }\end{array}$ & \\
\hline Gr6 Science & Heat & Photos and diagrams to illustrate effects of heat. & \\
\hline Gr9 Science & Light & $\begin{array}{l}\text { Photos to illustrate the importance of light for vision and refraction of } \\
\text { light and the effects of refraction. }\end{array}$ & \\
\hline
\end{tabular}


Observations made of their teaching learning processes revealed an increase of successful conduct of OER-integrated lessons on various topics such as Cell structure, Electricity, Plant diversity, Simple machines and Functions. OER were used at different steps of the teaching-learning process including engagement, exploration, elaboration and evaluation of students. A variety of OER materials such as videos, animations, diagrams, activities and texts have been used, and student motivation, interest and engagement in the lessons were greatly enhanced. Teachers expressed their opinions regarding their experiences of OER-integrated teaching as follows.

"We have linked OER at every step of our lessons, particularly at engagement, elaboration and evaluation. We also used different forms of OERs such as animations, diagrams, activities, video clips.... etc. We felt that we have refreshed our teaching-learning process through the integration of $O E R^{\prime \prime}$

"We used OER as better resources to explain difficult concepts to our students in a different as well as in an easy way. Students seemed to be engaged and highly motivated during the whole lesson when we integrate OER"

The findings indicated that, the integration of OER in the teaching-learning processes has significantly changed teachers' social behaviour related to sharing of knowledge, innovation and creativity. Further, their personality, leadership skills and team spirit also improved through the OER-integrated teaching practices.

\section{How has the integration of ICT and OER affected teachers' social relations?}

Data collected from classroom observations, interviews and teachers' self reflections were utilized to address the third research question regarding teachers' social relationships. Table 6 summarizes the findings from the reflections of teachers. 
Table 6: Changes in teachers' social relations.

\begin{tabular}{|c|c|c|c|}
\hline \multirow[t]{2}{*}{ Categories } & \multirow[t]{2}{*}{ Codes } & \multicolumn{2}{|c|}{ Supportive Quotes } \\
\hline & & Pre-Intervention & Post Intervention \\
\hline \multirow[t]{3}{*}{$\begin{array}{l}\text { Building } \\
\text { social } \\
\text { relationshi } \\
\text { ps }\end{array}$} & Sharing & $\begin{array}{l}\text {...We rarely shared } \\
\text { teaching aids...and } \\
\text { only with our } \\
\text { colleagues... }\end{array}$ & $\begin{array}{l}\text { Now we realized the } \\
\text { importance of } \\
\text { sharing...shared OERs } \\
\text { with colleagues and other } \\
\text { teachers.... }\end{array}$ \\
\hline & Forwardness & $\begin{array}{l}\text {...teaching in a remote } \\
\text { area.... resettlement is } \\
\text { still in progress after } \\
\text { the war.... struggled } \\
\text { and faced many } \\
\text { challenging } \\
\text { situations.... }\end{array}$ & $\begin{array}{l}\text {...we are the pioneers } \\
\text {....came forward as } \\
\text { resource person to } \\
\text { conduct OER awareness } \\
\text { workshops at schools for } \\
\text { other teachers... }\end{array}$ \\
\hline & Interactions & $\begin{array}{l}\text {...fear to interact and } \\
\text { to express our ideas.... }\end{array}$ & $\begin{array}{l}\text {...came forward and } \\
\text { shared the knowledge } \\
\text { through seminars with } \\
\text { our colleagues... }\end{array}$ \\
\hline
\end{tabular}

Participant teachers expressed their satisfaction and happiness on their social participation and how they developed social relationships as follows:

"We conducted OER awareness workshops at selected schools and happy to get the appreciations of the school society"

"We were able to integrate the OER in our team teaching. We shared the OERs we found with our peers"

Participant teachers, as leaders, have organized and conducted awareness workshops at schools to share their knowledge with their teacher community.

The findings showed that ICT and OER integrated teaching and learning has brought many changes in their social relationships. As citizens from the conflict-affected community, the teachers felt socially disadvantaged and lack many social skills. But the integration of ICT and OER in their teaching and learning motivated them to develop their social skills and to build up social relationships. They came forward as resource persons to conduct OER awareness workshops at schools for other teachers. They interacted with 
their peers and colleagues and shared OER among them. Despite facing various challenges the participant teachers integrated OER in their teaching and shared their knowledge with others. This achievement has improved their social relationships.

As the Northern part of Sri Lanka has suffered from the war for the last three decades, the people in this region were unable to use the modern technologies and innovative teaching-learning methodologies due to many challenges. Teachers in this region were also limited to use local resources for their teaching-learning process. After the war ended, teachers in some of the areas got opportunities to use the internet but their knowledge on OER was minimal. Teachers who participated in the project have recognized the importance of using OER in their teaching and sharing them with other teachers and helped them to improve their teaching.

The findings of the study revealed that, teachers' professional as well as social behaviours have been positively changed by the OER-integrated teaching-learning practices. Initially they were reluctant to come forward, not confident to express their ideas, not ready to work with others in teams, less interactive and shy. But ICT and OER integration has significantly changed their social behaviours. They joined together in teams and conducted workshops, published books, created OER in their mother tongue and shared them with the others. Teachers became socially active through the integration of ICT and OER in their teaching-learning process.

\section{Conclusion}

Northern Sri Lanka has been adversely affected by a crisis of nearly three decades and a majority of teachers lost their opportunities to experience the advancements of technology and modern education tools. At the beginning they were reluctant to break away their barriers, not ready to come out of the cocoon of fear formed around them by the war and to open-up themselves to the technically advanced world. However, ICT and OER integrated teaching-learning experience has served as a significant driving force for the change and opened up teachers' minds to cope with the modern educational tools and changed their professional as well as social behaviours in a positive manner, in a post-traumatic social setting. 


\section{Acknowledgements}

This work was carried out under a project conducted by the Faculty of Education at the Open University of Sri Lanka, with the aid of a grant from the International Development Research Centre, Ottawa, Canada, through the Wawasan Open University of Penang, Malaysia, as part of the Research on Open Educational Resources for Development (ROER4D) programme.

\section{References}

Allen, F. (1971). Socio-Cultural Dynamics: An Introduction to Social change. New York: Macmillan.

Atkins, D.E., Brown, J.S. \& Hammond, A.L. (2007). A review of the OER movement: Achievements, Challenges and new opportunities, A report to the William and Flora Hewlett foundation. Retrieved from http://www.hewlett.org/wpcontent/uploads/2016/08/ReviewoftheOERMovement.pdf

Butcher, N. (2011). A basic guide to open educational resources. Retrieved from: http://unesdoc.unesco.org/images/0021/002158/215804e.pdf

Cape Town Open Education Declaration. (2008). Cape Town Open Education Declaration: Unlocking the promise of open educational resources.

Retrieved from: http://www.capetowndeclaration.org/read-thedeclaration

Geser, G. (2007). Open educational practices and resources: OLCOS Roadmap 2012. Open eLearning Content Observatory Services. Retrieved from http://www.olcos.org/cms/upload/docs/olcos roadmap.pdf Ghavifekr, S. \& Rosdy, W.A.W. (2015). Teaching and Learning with Technology: Effectiveness of ICT integration in Schools. International Journal of Research in Education and Science. 1(2). 175-191.

Hennessy, S., Onguko, B., Harrison, D., Ang'ondi, E.K., Namalefe, S., Naseem, A. \& Wamakote, L. (2010). Developing the Use of Information and Communication Technology to Enhance Teaching and Learning in East African Schools: Review of the Literature. Centre for Commonwealth Education \& Aga Khan University Institute for Educational Development - Eastern Africa Research Report No. 1, DFID. Retrieved from http://www.educ.cam.ac.uk/centres/archive/cce/publications/CCE Rep ort1 LitRevJune0210.pdf 
Henslin, J. (1998). Essentials of Sociology: A Down -To-Earth Approach. (4 ${ }^{\text {th }}$ ed). Boston: Allyn and Bacon.

Karunanayaka, S. \& Naidu, S. (2014). Integrating Open Educational

Resources in Educational Practice: Practitioners stories. Nugegoda:

Open University of Sri Lanka. Retrieved from

http://www.ou.ac.lk/home/images/OUSL/publications/intergratingOERi nEducationalPractice.pdf

Kelegama, S. (2010). Socio Economic Challenges of Post conflict

reconstruction in Sri Lanka, Sri Lanka: State of the Economy 2010

Report. Colombo: Institute of Policy Studies of Sri Lanka.

Kelly, A. (2013). Technology can empower children in developing countriesif it's done right. The Guardian. Retrieved from

https://www.theguardian.com/sustainable-business/technologyempower-children-developing-countries

Kosma, R.B. (2005). National Policies that connect ICT based Education Reform to Economic and Social Development. Interdisciplinary journal on Humans in ICT environments. 1(2), 117-156. Retrieved from http://humantechnology.jyu.fi/archive/vol-1/issue-2/kozma1 117156/@@display-file/fullPaper/kozma.pdf

Kugamoorthy, S. \& Rajini, M. (2016). Opening up minds. In Karunanayaka, S. \& Naidu, S. (Eds.), Dreamweaving Open Educational Practices. pp 99106. Nugegoda: The Open University of Sri Lanka. Retrieved from http://www.ou.ac.lk/home/images/OUSL/publications/Dreamweaving\% 200pen\%20Educational\%20Practices.pdf

Kugamoorthy, S., Thanaraj, T., Lekamge, G.D. \& Zarookdeen, S. (2013).

Reaching the Unreached: Case Study of the Three Vanni Districts in Sri Lanka under the Post-War Context, Education Perspective, 2(1), 47-59.

Lingenfelter, P.E. (2012). The Knowledge Economy: Challenges and Opportunities for American Higher Education. In D.G. Oblinger ( Ed.), Game Changes: Education and Information Technologies. EDUCAUSE. Retrieved from https://net.educause.edu/ir/library/pdf/pub72031.pdf Mutekwe, E. (2012). The impact of Technology on Social Change: A Sociological Perspective, Journal of research in peace, gender and development, 2 (11). 226-238. Retrieved from http://www.interesjournals.org/full-articles/the-impact-of-technologyon-social-change-a-sociological-perspective.pdf?view=inline.

Rhema, A. \& Miliszewska, I. (2012). The potential of e-learning in assisting post-crisis countries in the building of their higher education systems: 
The case of Libia. Issues in informing science and IT, 9, 149-160.

Retrieved from http://iisit.org/Vol9/IISITV9p149-160Rhema033.pdf Thakrar, J., Zinn, D. \& Wolfendon, F. (2009). Harnessing Open Educational

Resources to the challenges of the Teacher Education in Sub- Saharan

Africa. The International Review of Research in Open and Distributed Learning, 10(4), 115-129. Retrieved from

http://www.irrodl.org/index.php/irrodl/article/view/705/1319 UNESCO (2010). ICT in teacher education: Policy, OER \& partnership. IITE, 2010 Nov 15-16, Russia. Retrieved from http://unesdoc.unesco.org/images/0019/001936/193658e.pdf UNESCO (2012). Paris OER Declaration. Retrieved from

$<$ http://www.unesco.org/new/fileadmin/MULTIMEDIA/HO/Cl/Cl/pdf/Ev ents/Paris\%200ER\%20Declaration 01.pdf>

UNESCO/COL (2011). Guidelines for Open Educational Resources in Higher Education. Retrieved from http://unesdoc.unesco.org/images/0021/002136/213605E.pdf United Nations Agency for International Development (USAID) (2013). Using Technology to Deliver Educational Services to Children and Youth In Environments Affected By Crisis and/ or Conflict, Final Report 2013. Retrieved from https://quality4digitallearning.org/wpcontent/uploads/2016/03/ICTs-in-Conflict-Compendium-FINAL.pdf Vago, S. (1992). Social Change. London: Halt Rinehart and Winston Wiley, D. (2014). The access compromise and the $5^{\text {th }} R$. [Weblog]. March 5 2014. Retrieved from http://opencontent.org/blog/archives/3221 Yuan, L., MacNeil, S. and Kraan, W. (2008). Open Educational Resources Opportunities and Challenges for Higher Education. Retrieved from http://wiki.cetis.ac.uk/images/O/Ob/OER Briefing Paper.pdf 